\title{
Erós sofistés a Erós mythoplokos
}

\section{Tomáš Hejduk}

Teze, již zde chceme dokazovat, v širších souvislostech patří k tvrzení, že Sókratés není konvenční účastník symposií, ani konvenční pederastický erastés či erómenos. Nejobecněji a nejrozhodněji toto tvrzení platí podle nás proto, že na rozdíl od dobového symposiastického, pederastického či homofilního sdružování se oddaných přátel (filos hetairos), jejichž cílem je poškodit neprrítele a prospět příteli (viz např́íklad básnická sbírka Theognidea), je Sókratés svojí techné erotiké hořkosladkým rivalem především pro své prrátele a milované. Zde nicméně chceme navzdory zřejmé podivnosti Sókratova způsobu erotiky načrtnout jeho blízkost jedné $\mathrm{z}$ archaických tradic. $\mathrm{V}$ tomto ohledu jsou následující rádky také polemikou s dominující představou Sókratovy či Platónovy netradiční kritiky pederastie, respektive kritiky tradičního pederastického eróta. Konkrétně jde o to, načrtnout určité rysy silné návaznosti Sókratova pojetí lásky ze Symposia (potažmo Faidra a dalších dialogů) na lyrické koncepty eróta coby součást pederastické kultury, ${ }^{\mathrm{i}}$ a tak poukázat na to, že Sókratův erós nemusí být chápán jako zásadně netradiční. ${ }^{\text {ii }}$

\footnotetext{
${ }^{i}$ Následně se věnujeme srovnání Sókrata výhradně se Sapfó jako představitelkou staré, neprofesionalizované a nikomu nezaprodané „,melické“ lyriky.

${ }^{i i}$ K Sókratovu netradičnímu chápání pederastie či stavění lásky filosofovy do kontrastu $\mathrm{k}$ lásce pederastické (tímto termínem zde máme na mysli starořecký výchovný proces) viz např́klad Cajthaml 2007. Autor staví do opozice toužení filosofického milujícího po ctnosti a nesmrtelnosti a touhu po sexuálním uspokojení u tradičního pederasta. Nevidíme však nějaké opravdu silné argumenty pro tvrzení ,...one of the chief aims of a Greek pederast has always been the satisfaction of his sexual desire...", anebo pro tvrzení, že pederast toužil více či stejně po sexuálním uspokojení jako po ctnosti či vzdělání. I kdyby se to dalo vyvodit z Pausaniova popisu pederastických praktik v Platónově dialogu Symposion, těžko to doložit v kontextu dalších textů či starořeckých reálií. Jiná specifičnost filosofické lásky dle Cajthamla spočívá v převracení rolí milující -
} 
U platonika Maxima z Tyru najdeme zajímavé spletení epitetonů boha lásky, které vedle sebe staví Sapfina Eróta mythoplokon a Sókratova Eróta sofistén. Bok po boku jsou zde mistr moudrosti a snovač př́iběhů. ${ }^{i}$ Jak již výše řečeno, zde se chceme soustředit jen na otázku, zda lze tento řádek chápat jako juxtapozici odlišných erótů lyriky a filosofie, anebo naopak poukaz na určitou soupatřičnost obou erótů.

Na základě takovéto konstelace přídomků u Maxima bychom mohli spekulovat, že jde o kontrast: Sókratés svojí zvláštní moudrostí, „sofistikou“ překonává lyrické fantazie o erotických zápletkách (anebo alespoň k nim tvoří promyšlenější pandán). Nebo by se nabízela opačná spekulace, že Sókratés v takovém splétání mýtů vidí jakousi sofistiku, ${ }^{\text {ii }}$ od níž se např́ič nejen Platónovými dialogy spíše distancuje. Splétání příběhů přece lze dost dobře v Platónových dialozích spojit se sofistikou jako přemlouváním či ujišt'ováním sebe i druhých o své pravdě, o svém vidění světa. My se přikláníme k trretí možnosti, v jejímž rámci tvrdíme, předběžně řečeno, že Sókratés navazuje svým ,erós sofistés“ na Sapfinu činnost. Oproti dvěma zmíněným, dle nás příliš radikálním, výkladům „překonání“ a „distancováni““ tak stavíme třetí možnost „,rozvíjení“ tradice. Neboli: filosofovi a básnířce je společný nejen erós, ale i oba př́ídomky (už proto, že se oba podstatně týkají eróta samého, lze předpokládat, že do té míry, do níž je Sókratés spojován s erótem, musí být spojován i s těmito př́idomky). ${ }^{\text {iii }}$

milovaný. O obvyklosti takovéto „eroticko-edukační hry“ ale svědčí i autorem citovaný Ch. Gill. Tímto nechceme říci, že Sókratova erotika je tradiční, nýbrž jen to, že př́ípadné rozdíly mezi Sókratem a tradicí jsou jiné či jemnější.

${ }^{\mathrm{i}}$ Maximos z Tyru 24.9: ton Erôta Sôkratês sophistên legei, Sapphô muthoplokon. Srv. Sapfó fr. 125, Platón, Symposion 203d. Prapodivnost tohoto spojení zmiňuje Carson 1986, s. 170.

ii Takto např. Carson 1986, s. 170.

iii Samožrejmě, že Sapfó je jen př́kladem tradice, k níž bychom mohli připojit další básníky. Ovšem Sapfó zároveň představuje výjimečnou básniřku, která se velmi blíží Sókratovi v jeho ,podivuhodnosti“, atopos: např. v tom, že neslouží žádné instituci, rituálním či vzdělávacím programům. Srv. např. Parker 1993, s. 
Východiskem budiž to, že charakteristiky „sofistés“ i „mythoplokos“ se objevují u obou, lyričky i fillosofa, v zjevně (rovněž) kladném smyslu. Životy Sapfó i Sókrata jsou erotiky plné, Sókratés i Sapfó se k erótu a lásce napříc slovy, které jim tradice připisuje, vehementně hlásí. Kontextem Sókratova př́íomku sofistés je chvalořeč na Eróta a stejně je tomu u Sapfiných básní. Přitom navíc filosofa s básnî́rkou spojuje opozice proti prostému chvalořečení: ani jeden si eróta a lásku neidealizuje a $v$ jednom př́ípadě verše, v druhém dialektické rozpravy pracují s láskou vždy ambivalentní (u Sapfó viz napřr. př́ivlastek glukupikron). Proto se také v Sapfiných verších i Sókratově řeči objevují popisy velmi ošemetné (viz dále), aniž by ale eróta celkově kompromitovaly a vylučovaly jeho chvályhodnost. Tímto celkovým kontextem kritického ocenění a plného proživání lásky, tj. v její ambivalenci, jsou si tedy filosof a lyrička blízcí. ${ }^{\mathrm{i}}$ Tvrzení, že př́domky, jak je vedle sebe postavil Maximos, patř́i rozumně k sobě právě jako pro filosofa i básnířku kladné, byt’ ambivalentní hodnoty, bez nichž by jejich činnost (filosofie a básnění) nebyla možná, dosvědčují ale i další důvody. Prvním místem, kde lze hovořit o Sókratově ploké, je strojení úkladů krasavcům. Sókratés jako zastánce pravdy na symposiu, které popisuje Platón, intrikuje. Začne to už tím, že ten večer jde za pravdou tak, že změní vizáž, umyje se a nastrojí a jde za Agathónem upravený jako Agathón (174a). ${ }^{\text {ii }} \mathrm{K}$ jeho intrikám poukazuje také svědectví

325-6: „Sappho is a woman, independent of any demonstrable civic role, a lyric poet performing solo songs..."

${ }^{i}$ K napětí mezi věčnou ambivalencí eróta a potřebou tuto ambivalenci překonat či zvládnout viz např. Špinka 2009, s. 129 a n. Zde se kloníme k názoru, že Sókratés neusiluje o „překonání“ ambivalence eróta, ale „pouze“ její „zvládnutí“.

${ }^{i i}$ Srv. Osborne 1996, s. 91, podle níž je v dialogu Symposion sókratovštější Sókrata Aristodémos, který je do filosofa zamilovaný a dočasně přebírá jeho méně uhlazenou cestu. S výkladem Osborne nesouhlasíme v bodě, kdy tvrdí, že v tomto dialogu Sókratés neusiluje o pravdu. Také se kloníme spíše k tvrzení, že Aristodémos je extrémním případem podlehnutí žáka učiteli či vyhrocení učitelových slov, a v rámci dialogu Symposion tak tvoří opačný extrém vztahu k Sókratovi (učitelovi) ve srovnání s Alkibiadem. Samozřejmě o přiblížení pravdě 
Alkibiada: ${ }^{\text {i }}$ Sókratés se zde ukazuje jako ten, kdo (minimálně co do své erotické techné) klame druhé (eksapataó, 222b) - Alkibiadés na něho strojí pasti (217cd) a zatím se sám do pasti chytá: erotik Sókratés je dvojnásobný epibúlos, nebot' omámí omamného, aniž se sám dá omámit. ${ }^{i i}$ Celou paletu filosofova pletichaření bychom snad mohli spojit s jeho provokativním držením teze, že kdo chce - nebojme se použít kouzelný oxymóron opravdu lhát, tj. úmyslně vodit druhé za nos či klást pasti (což je lepší než dělat to neúmyslně; v tomto smyslu je Sókratova „nepravdivá“ první řeč v dialogu Faidros snad lepší než řeč Lýsiova, která si svoji nedostatečnost neuvědomuje), musí znát pravdu a myslet (viz třeba Hippiás Menši). ${ }^{\text {iii }}$ Sókratés v Symposiu či v druhé polovině dialogu Faidros (269e-270a) to přece ř́ká také, jen naopak - kdo chce krásně a dobře mluvit, kdo chce umět ,vodit duše“" (psychagogia), musí znát pravdu a myslet. K tomuto vodění duší či pravé rétorice patří, jako ke každému velkému umění (v Sókratově případě techné erotiké, Phaedr. 257a), i důvtipné mluvení (adoleschia). Výraz adoleschiaiv jinak ironický či pomlouvačný lze podle

lze mluvit i u dalších řečníků, viz např. Sheffield 2006, která poukazuje na to, že všichni řečníci v zásadě připravují půdu svými částečnými náhledy pro Sókratovo odkrytí celku (pravdy); ovšem připomíná, že bez Sókratova ucelení a upřesnění vlastně o pravdu nejde.

${ }^{\mathrm{i}} \mathrm{K}$ diskusi o autentičnosti portrétu historického Sókrata v Alkibiadově řeči, případně v celém dialogu Symposion (především v Diotimině řeči) viz Prior 2006. ${ }^{\text {ii }}$ Srv. Sókratés strojící nástrahy: „,zase na mě číháš (ellochaó)... “, „,nastrojil (méchanaó) jsi to tak, abys ležel vedle nejkrásnějšího z celé společnosti““(213c, 215c-d, 216d); podobně nemožnost Sókrata opít v Symp. 176c, 214a; obecně o Erótu epibúlos v Sókratově (Diotimině) řeči: 203d. V dialogu Faidros minimálně první Sókratovu řeč jako ,úmyslné lhaní“ či alespoň „nevyslovení celé pravdy“ lze rovněž vyložit.

iii Srv. výklad Hobzy 2002, který podotýká, že Sókratés se od svých tezí distancuje, naprríklad když v závěru tvrdí, že „bloudí“ (Hipp. Min. 376c). My zde ale nezpochybňujeme, že Sókratés své výklady pronáší ironicky a následně je „,dialekticky“ doplňuje, nýbrž tvrdíme, že toto „pletichaření“ patří k jeho „způsobu“ zkoumání či zacházení s druhými.

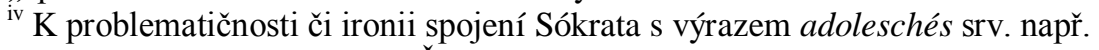
Edmunds 2006, s. 414 a n. či Špinka 2009, s. 191-3. Sókratés byl spolu se sofisty zřejmě běžně chápán a charakterizován jako adoleschés, což je výraz, kterému lze 
nás rozumně vyložit v př́ípadě Sókrata právě ve vztahu ke strojení úkladů krasavcům. Pokud budeme vykládat adoleschii jako ironickou parafrázi Sókratovy dialektiky, pak lze říci, že strojení úkladů krasavcům je součástí sókratovské dialektiky.

Pokud pak budeme pasáž ze Symposia, kde se ř́́ká, že Erós je po otci sofistés, číst a vysvětlovat jako celek, pak zde je odkaz k Sapfině výrazu mythoplokos takřka explicitní, nebot' se zde praví, že Erós také v kontextu tohoto dědictví po otci „stále osnuje nějaké nástrahy“ (aei tinas plekón méchanas). Zkrátka, jestliže Sókratés s Diotimou dochází k závěru, že Erós není ani dobrý ani krásný ani moudrý, pak je jasné, že to, co Erós zdědil po Porovi (a co má Sókratés od Eróta), není moudrost, ale spíše vztah k moudrosti, schopnost směřovat (za pomoci intrik, epibúleó) k ní. ${ }^{\mathrm{i}}$ Erós má epibúlia, schopnost obmyslnosti, schopnost přemyslet, převézt ostatní. Tato schopnost je Erótovým prostředkem k sahání po moudrosti, již postrádá: Erós ví, jak se stávat moudrým. Postrádá moudrost, ale už uvědomování si této bídy (aporia) je znakem nebídnosti, tj. chytrosti (euporia) dostatečné k jejímu nabývání (203d4-7). ${ }^{\mathrm{ii}}$ Pokud vyložíme s Carson prrívlastek „sofistés“ jako „mistr moudrosti“, pak jen v tomto smyslu - ne mistr coby majitel moudrosti, nýbrž mistr coby znalec cesty $\mathrm{k}$ moudrosti, tj. znalec erotiky. Vhodnějším přkekladem pak bude ,mistr erotiky“, neb ta je Sókratovou techné a znalostí: „v ničem jiném se nevyznám (epistasthai) než ve věcech lásky (ta erótika)“ (177d). To, že

rozumět ve významu upovídanosti či planého tlachání, ale i důvtipného, důkladného promýšlení či přemlouvání. Kromě řečí, které svedou Faidra ve stejnojmenném dialogu od obdivu k Lysiovi k obdivu k Sókratovi (a také na samotu za město a zpět), zahrnuje Sókratovo techné erotiké také vědění, kdo je správný milovaný, jak se chovat k milovanému, koho s kým dát dohromady atp. viz např. dialog Theaitétos či Lysis. At' už tyto pasáže budeme číst jakkoli metaforicky, je v nich ,intrikaření“ (,plokon“) přítomné.

${ }^{i}$ Poros znamená cestu, dráhu, postup, brod, průlinu, lest, východisko, úskok. Dle Šediny (s. 188) jako syn Dia a Métis ,ztělesňuje zřejmě Poros pro Platóna jakýsi obrazný přechod od básnického mýtu k nové metafyzické symbolice“.

${ }^{\text {ii }}$ Srv. Sheffield, s. 61-2. 
problematické výrazy (epibúlos, sofistés, goés, farmakeus, plekón méchanas) lze rozumně a beze studu - když ne pochvalně, pak také ne hanlivě - zmínit u Eróta (a analogicky u Sókrata) ${ }^{i}$ zajišt'uje kontext této pasáže, v němž je jasně řečeno, že jde o vztahy k moudrosti, k dobrému a krásnému, tj. o filosofii: „strojí úklady (epibúlos) krásným a dobrým, je zmužilý, smělý a vytrvalý, mocný lovec, jenž stále osnuje nějaké nástrahy, žádostivý premýšlení a vynalézavý, milovný moudrosti po všechen život, mocný čaroděj, kouzelník a sofista." (203d) Erós sofistés tak nutně není adikos, jak se lze dočíst třeba u zjednodušujícího Xenofóna. ${ }^{\text {ii }}$

Tímto netvrdíme, že jedna ze Sókratových podmínek krásné a dobré řeči, rétoriky či filosofie, jak o ní mluví např. v dialogu Faidros, totiž podmínka „důvtipně mluvit“ je totožná s tímto pletichařením. Tvrdíme jen, že takové pletichaření je součástí této činnosti, přičemž necháváme stranou otázku, jestli se týká jen nižších stupňů scala amoris, jak je popisuje Diotima, či jen výchovy naivních mladíků (např́klad Faidra), anebo je do určité míry stále nutně prrítomné u všeho myšlení majícího filosofické ambice, tj. směřujícího $\mathrm{k}$ moudrosti a dobru. ${ }^{\text {iii }}$

Oproti výkladům vyvozujícím z této Sókratovy ošemetné erotické činnosti „falešné přátelství“ (vzbuzuje očekávání, jež nezamýšlí naplnit, křivdí atd.) $)^{\text {iv }}$ tvrdíme v kontextu předcházejícího výkladu, že jde o legitimní eroticko vzdělávací proces či legitimní erotiku jako součást jistých dobrých úmyslů. Sókratés-intrikán (ve smyslu svůdce mladíků, ale i důsledného, vyvracejícího či dialektického myslitele) dává dobrý smysl právě v tomto kontextu Eróta epibúla, kdežto když nevezmeme tento erotický kontext vážně, dospějeme k moralizování, v jehož rámci nutně Sókrata odsoudíme

\footnotetext{
${ }^{\mathrm{i}}$ Interpreti se vesměs shodnou, že Sókratés (v popisu Alkibiada) a Erós v pojetí Sókrata (Diotimy) jedno jsou.

${ }^{i i}$ Xenofón, $O$ Kýr. vych. 6.1.41.

iii Srv. McCormick 2007, který připouští analogii eroticko-výchovných pletich Sókrata s jeho technikou dialektického křižzového výslechu.

${ }^{i v}$ O Sókratovi coby nedobrém př́teli viz např. McCormick 2007.
} 
jako špatného přítele. Jinak řečeno, je třeba hovořit bud' o erotickém vztahu (erós) nebo o přátelství (filia). Zamilovaní se k sobě chovají jinak než přátelé. Tak i u Sókrata po poměrně drsném či ironickém, řekněme iniciačním ritu erotických soupeření, může případně přijít fáze přátelství. (Bude ale obtížné určit, zda Sókratés-erotik někde v dialozích skutečně již vystupuje spíše v roli prŕitele - například snad v dialogu Faidón. Jelikož Sókratés je předně jakýsi zvláštní vychovatel a filosof, jeho činnost musí spočívat právě $v$ erotice, do jejíhož konceptu běžné přátelství prostě nezapadá. Jak i citovaný McCormick bere v potaz, byt' nepřijímá jako rozhodující - cituje T. Robinsona - u Sókrata jde o lásku a pravdu a ne o přátelství a osobní ctihodnost. Platónova postava Sókrata tak nabízí spíše jakousi erotickou filii, která je ovšem netradičním pendantem filie známé z hetairií a podobných starořeckých sdružování podobně smýšlejících lidí.)

Spojitost Sókratova pletichaření $\mathrm{s}$ významem slovního spojení mythoplokon lze dále vyvozovat rovněž z toho, že Sókratovo zahrávání si s mladíky se děje stejně jako Sapfiny pletky s ženami výhradně v řeči, slovem (mythos, logos): ${ }^{\text {i }}$ V prŕpadě Alkibiadovy obžaloby Sókrata za zesměšnění nejde tolik o to, že ho Sókratés odmítl stran sexuálního flirtu, jako o Sókratovu aktivitu slovní a dialektickou. Stud sice Alkibiadés popisuje také při odmítnutí „,vyhovění ve věcech sexuálních“, hlavně ale mluví o „ostudném zotročení“ Sokratovými řečmi (215c-216c, 218a-b). A pokud máme brát spojení Sókrata $\mathrm{s}$ erótem vážně, pak musíme eróta spojovat $\mathrm{s}$ tímto druhým př́íkořím a ne (jen) s konec konců směšnými věcmi sexuálními. Zahrnutí eróta do ,vážné oblasti“ řekněme dialektiky a vzdělávání k ctnostnému životu ovšem neznamená, že erós ztrácí veškerou

\footnotetext{
${ }^{\text {i }}$ Dokonce vcelku pravidelně lze Sókratovu řeč, jinak spíše spojovanou s výrazem logos, spojovat s „,básněním“: ve Faidru tak palinódie, řeč, kterou si Sókratés získá Faidra na svoji stranu, je zvána mýtem a ,je pronesena po všech stránkách básnicky a zvláště básnickými slovy“ (257a). Srv. také slova Alkibiadova o tom, že Sókratés nejenže uchvacuje pouhými , ̌rečmi“, tj. bez pomoci nějakého nástroje (zde je možný rozdíl $\mathrm{k}$ lyrice), ba že dokonce stačí ony řeči slyšet od někoho jiného než Sókrata (215c-d).
} 
svoji „lehkost“ - v duchu předchozího právě nějak „ulevuje“ serióznosti této zásadní stránky života. Třeba tak, že i v diskusi o vážných věcech udržuje smysl pro krásu, tvoření či „,básněni“. Víme přece ze Symposia, že Erós je poiétés a udělá básníka i z nemúsického jedince (196e). ${ }^{\mathrm{i}}$ Takovýto výklad směrem k součinnosti eróta sofistés s erótem básnivým podporuje i fakt, že v Sókratově době jeden $\mathrm{z}$ nejrozšířenějších významů výrazu sofistés byl právě „básník“, ,„hudebník“. ii

Jinak řečeno, Sapfin erós jako snovač slov je podle nás výsostným předobrazem eróta Sókratova, protože oba přeskakují do jiného, s trochou nadsázky řekněme ,vymyšleného“ světa. iii Stejně jako u Sapfó, nevede erós ke konzumaci milovaného-lásky (at' už v manželství či v sexuálních stycích) ani u Sókrata: touha Sapfó vrcholí psaním, básněmi podobně jako touha Sókratova otázkami, dialektickými řečmi či mýty vyprávěnými

\footnotetext{
i Tuto Agathónovu tezi podporuje i Diotima, viz např. Stern-Gillet 2007, kde rozebírá, zda u Agathóna jde o poiésis ve smyslu tvoření nebo podněcování $\mathrm{k}$ tvorbě.
}

${ }^{i i}$ Edmunds 2006, s. 418 a n. Sókratovu nakloněnost (jistému typu) básnictví rozebírá napřr. Nussbaum, s. 405 a n., kde filosofovi připisuje rozum vedený k poznání, dobru či řádnému životu skrze osobní zaujatou lásku, odkázanost na druhého, náhodu a křehkost, vášně, emoce či city. Sókratés ve Faidrovi je músikos (248d), zhodnocuje músické obory. Ovšem ne tak, že by obhajoval básnictví jako takové, nýbrž ztotožněním pravého músika s oddaností filosofii (slouží Kalliopě a Úranii). Filosofie (tj. také tvorba a užívání mýtů a básnické řeči) je nejvyšší músiké. V nejvyšších patrech filosofie a básnictví splývají: „milovník moudrosti, krásy či nějaký služebník mús“ (248d, srv. 259d). Znamenitý básník je filosof a vice versa; naopak obyčejný poiétés, řemeslný básník (např. inspirovaný penězi či nátlakem tyrana) je až na šestém místě (248e). Sapfó pak - viz odkazy ve zbytku textu - jistě nepatří k těmto řemeslným básníkům.

iii Např́klad v dialogu Hipp. Min. 372b Sókratés říká explicitně, že ,o skutečných věcech nevím, jak to s nimi je“" (tón pragmatón hé echei esfalaimai kai úk oid' hopé esti). Jiným úhlem pohledu na toto „vymýšleni““ je popis Sókratova stranění se lidských zájmů a zabývání se zájmy božskými, theopragmeia; viz např. Barabas 2000. 
druhým (např. palinódie dialogu Faidros přesvědčující mladého Faidra). ${ }^{i}$ V Symposiu ovšem namísto konzumace nabízí Sókratés „za zdání krásy krásu opravdovou“, anti doksés alétheian kalón. Proto by bylo možné namítnout, že tradiční erós mythoplokos je symbolizován spíše ostatními řečníky v Symposiu, nebot' právě oni si na rozdíl od Sókrata vymýšlejí: „zahrnuji predmět chvály nejvelkolepějšími a nejkrásnějšími vlastnostmi, at' už jsou ve skutečnosti takové nebo ne; jsou-li nepravdivé, na tom tedy nic nezáleži“" (198e). Pro jejich „vymýšlení“ je přitom typické, že bez námitek se v plynulé návaznosti střídají v chvalořeči (enkómion, epainos). Tak podobně jako třeba u Theognida jde v první řadě o př́jemnost a pohodu (glukus kai harpaleos), vzájemné pobavení (diatribé, 177de) se mezi svými. Sókratés se jako jediný staví zásadně proti a odmítá takovéto vymýšlení si ve prospěch pravdy (198b-199b). Pokud se ale budeme striktně držet lyriky z pera Sapfó, pak je jasné, že ani její erós mythoplokos nemá s takovýmto „chvalořečícím vymýšlením si“ co dělat. Ona, jak jsme již řekli - stejně jako Sókratés - tematizuje lásku v její ambivalenci, eróta vykresluje kriticky v jeho celistvosti, která je hořkosladká. ii

Výraz „mythoplokos“ v kontextu Sapfiny lyriky, stejně jako výraz „sofistés“ v kontextu Sókratovy erotiky či jen dialogu Symposion představují tedy svojí nekonzumností „,vymýšlení pravdivé“ spíše než „vymýšlení nevázané“, vlastní ostatním řečníkům pitky. Zde lze opět tento termín ukazující se $\mathrm{v}$ Sokratových řečech podpořit jedním $\mathrm{z}$ běžných významů výrazu sofistés v Sókratově době, a sice „vynálezce“ či „objevitel“", čili ten, kdo si nevymýšlí ve smyslu lhaní, nýbrž ve smyslu

\footnotetext{
${ }^{\mathrm{i}} \mathrm{V}$ druhé půli 20. století se objevují studie dokazující, že u Sapfó nelze doložit nic (výchovnou instituci, pederastické či svatební rity, sexuální styky atd.) než že byla básniřkou, přičemž básně psala pro ně samé a alespoň primárně ne kvưli vzdělání a pod. Viz např. Parker 1993.

${ }^{i i}$ Sapfó nepatří do tradice typických „,naučných básní“. Namísto „teoretických slov“ vychází z niterné zkušenosti - podobně i Sókratés (viz např. palinódie v dialogu Faidros) - aby ovšem pak tuto zkušenost zobecňovala a reflektovala, viz dále.
} 
nalézání nového, tvoření. ${ }^{\mathrm{i}} \mathrm{I}$ když komplexní teorii idejí připustíme teprve u Platóna, Sókratés produkuje dialektické řeči, v jejichž rámci nazírá cosi „jiného“, např. již zmíněné auto to kalon. Ale Sókratovo „vymýšlení“ nemusíme spojovat až s nejzazšími předměty typu idejí, nebot' již vymýšlení obrazných mýtů, podobenství atp. lze řadit do této erotické sofistiky či „plokéc. ii U Sapfó sice lze zdůrazňovat tvorbu epithalamií a svatbu, coby poslední a rozhodující kontext jejího myšlení či básnění, ovšem tento výklad se zdá být překonán interpretacemi popírajícími Sapfinu činnost coby zasvěcovatelky v rámci přechodových rituálů a její činnost vidí spíše jako analogickou Sókratově, tj. své řeči vede či básně zpívá na symposiích, obklopena vrstevnicemi. At' už je to jakkoli - osobně nevidíme striktní rozpor mezi zasvěcováním mladých a účastí na symposiích, ba naopak (ovšem jinak souhlasíme s interpretací popírající Sapfino rituální zasvěcování, svatební činnost či programové vychovatelství) ${ }^{\mathrm{iii}}$ - jisté je, že Sapfó také tematizuje krásu samu a odhlíží od konkrétních těl, jedinců či prožitků (byt' ne v systematičtějším typu řeči filosofické). ${ }^{\text {iv }}$ „Jinakost“ či ,vymýšlení“ u Sapfó lze zkrátka spíše než se

${ }^{i}$ Viz např. Edmunds 2006, s. 419-421.

ii Viz např. i v tomto směru velmi uměřený Špinka 2009, s. 75: „Sókratův důkaz prospěšnosti lásky tak bude pouze částečně spočívat na síle logických argumentů. Neméně důležitou roli v něm bude hrát schopnost nabídnout nový a objevný pohled na nás samé a na svět našeho života.“

iii Např. viz Parker 1993, s. 309-351.

${ }^{\text {iv }}$ Toho si všímají již antičtí komentátoři - viz např. právě Maximos z Tyru srovnávající Sapfó se Sókratem (18.9): „Čím jiným byla láska Lesbičanky než Sókratovým uměním lásky (techné erotiké)? Zdají se mi oba praktikovat lásku každý svým způsobem, ona ženským, on mužským. Ř́ká se totiž, že oba milovali mnohé a uchvacovalo je vše krásné. Alkibiadés, Charmidés a Faidros byli Sókratovi tím, čím byly Gyrinna, Atthis a Anaktoria pro Lesbičanku. A čím byli pro Sókrata soupeřiví umělci (antitechnoi) Prodikos a Gorgiás a Thrasymachos a Protagorás, tím byly pro Sapfó Gorgé a Andromeda. Jednou je kárá (epitima), jindy vyvrací (elenchei) a ironizuje (eiróneuetai), zrovna tak jako Sókratés.“ $\mathrm{Z}$ novějších popisů viz např. Stigers 1979, s. 465: „The original emotions themselves must have their stimulus in the poet's experience, but the process of 
svatbou spojovat především s vytvářením alternativního světa k světu konvenčnímu: „Sappho used the special conditions of lesbian love to create an alternative world in which male values ... are not dominant, and within which mutual desire, rapture, and separateness can be explored as female experience“. Právě takto směřované výklady zdůrazňující Sapfinu ,jinakost“", neredukovatelnost na aktivity vzdělávací, cvičící či rituální, lze dobře spojit s argumentem, že Sókratés tenduje k erotice ženské, pro kterou právě byla typická nekonvenční, nekonzumní touha tvořivá, vztah reciproční a ne hierarchizovaný. Sókrata v tomto duchu pojí se Sapfó jeho „ženská“ ‘̌eč v Symposiu, která vyzdvihuje proti po rozkoši a vlastnění bažícím jedincům jedince tvořící, nekonzumní a reciproční. ${ }^{\text {ii }}$

Výše jsme ukázali, jak je fiktivně erotický, tvořivý charakter Sókratovy moudrosti paradoxně spjat s tím nejméně zdánlivým: krása sama je neměnná, věčná (210e-212a). Zásadní rozdíl řečí Sókratových (např̀. V Symposiu oproti předcházejícím řečem Pausaniově či Agathónově) je také v rovině reality: tělesná, pozemská krása a atraktivita je postavena do opozice ke kráse inteligibilní, duševní, mimosvětské. Tuto rozdílnost lze z pozice běžného života popsat jako nahrazení reálného (řekněme empiricky vykazatelného) vymyšleným (srv. pozn. 21). Tímto směrem se zde nicméně nechceme při vysvětlování Sókratovy fiktivnosti dávat, protože ta podle nás nespočívá teprve $\mathrm{v}$ odkazu $\mathrm{k}$ povaze vrcholného předmětu touhy a poznání. Fikci s sebou totiž nese již erotická touha samotná. Jak je známo, v erotice fungují milostné trojúhelníky, erós typicky nenachází uspokojení v dvojici, ale hledí přecházet $\mathrm{k}$ třetímu místu, jedinci, úhlu, který v prvé řadě tvoří překážky (žárlivý sok, chránící rodiče, puritánská výchova, stud atp.) snadnému uspokojení touhy, a tak

clarifying them requires the poet to refine, transform, extrapolate experience imaginatively, perhaps beyond recognition."

${ }^{\mathrm{i}}$ Stigers 1979, s. 471.

ii Podrobněji viz Halperin 1990, který ovšem problematizuje ženskost Diotimy, neb její slova jsou venkoncem výtvorem Platóna, tj. psaní mužského. 
touhu a eróta vlastně posiluje. Právě v tomto erotickém pohybu mezi třemi místy např́íklad výše citovaná Carson vidí prvotní případy myšlení coby aktu, kdy jedincova mysl musí přecházet prostor mezi známým a neznámým tak, že spojí jedno s druhým, a udrží na zřeteli jejich rozdílnost. V prrípadě Sókrata lze parafrázovat: kdykoli Sókratés vede svůj obvyklý dialog, jeho mysl přechází od Faidrů a Alkibiadů ke kráse či dobru jako takovým (vynecháme-li mezistupně, jež zmiňuje Diotima) a vidíce v obou totéž, vidí a myslí jejich jinakost. Právě to je prostor, kde operuje erós, a jeho opomenutí, tj. opomenutí rozdílu krása - konkrétní člověk, se rovná nepochopení a potížím, které mívají Sókratovi partneři. Alkibiadés v Symposiu nerespektuje erotický meziprostor a snaží se Sókrata-eróta dostat k sobě, tj. zničit (životní) prostor mezi nimi, respektive zbavit Sókrata-eróta dimenze krásy samotné a redukovat ho na krásu svoji.

V tomto smyslu vytváření životního prostoru v natahování se po něčem dalším-třetím rozumíme Sókratově a Sapfině erotice, erótu sofistés či mythoplokos. ${ }^{i}$ Jelikož tento prostor tvoří erotická mánie, posedlost, která stř́ílivému nutně uniká (Phaedr. 245b), mluvíme o jeho „,vymyšlenosti“ či „rozvinutí“ (ploké). A rovněž v tomto duchu rozumíme Sókratovu přijetí teze, že „každý se stává básníkem ... kohokoli se dotkne Erós“ (Symp. 196e). Pokud tuto v dialogu nezpochybňovanou Agathónovu tezi spojíme s běžně přijímaným faktem silné podobnosti, ne-li totožnosti Eróta se Sókratem či Sókratovo známé hlášení se k erotickému umění, pak lze vyvozovat závěr o Sókratově poiésis.

Máme-li spolu s odkazy na pravdu vzít vážně Sókratova slova o tom, jak je jeho moudrost či pravda „chatrná a pochybná a jako pouhý sen“ (175e),

\footnotetext{
${ }^{\mathrm{i}} \mathrm{U}$ Sapfó lze v tomto ohledu za locus classicus považovat fr. 31 (čes. př. R. Hošek): „Nesmrtelným zdá se mi roven bohům/onen muž, jenž naproti tobě sedí/tváŕí v tvář a naslouchá zblízka tvému sladkému hlasu...." Přitom našemu výkladu odpovídá také interpretace tvrdící, že zde nejde o reálného soka v lásce, a tak ani o soupeření či žárlivost, nýbrž o rétorickou figuru pracující s vymyšleným „božským“ pozadím, na němž se teprve řádně ukáže Sapfina hodnota. Viz např. Furley 2000.
} 
pak se nabízí právě spjatost této skepse s erotikou, tj. v rámci předloženého výkladu s přecházením mezi třemi (ontologicky různými) místy. Ostatně není náhoda, že charakteristika moudrosti ze Symposia - pochybná, amfisbétésimos - je stejná jako charakteristika eróta z Faidra (263c). Chatrností, sporností a snovostí není charakteristická krása jako taková, která, jak víme, je „solidní“. Chatrná je naše cesta ke „skutečnosti“, „snové، je pozemšt’anovo vidění či žití souvislosti lásky ke kráse s láskou ke konkrétní krásné bytosti z masa a kostí. Tato „fiktivnost“" by se souhrnně dala označit jako kapricióznost „bytí mezi“ (viz Erótův status „mezi“ z Diotiminy řeči: daimón metaxy), přecházení mezi světy (erotická triangulace). A zde se nám vrací druhý bod Sókratovy či Platónovy tendence k ženské erotice: Sókratův erós není hierarchický, nýbrž reciproční:i ,„̌̌ebř́ík lásky“ z Diotiminy řeči neznamená, že dostat se nahoru znamená získat vyšší status, kterého se „nižši““ stádia netýkají nijak jinak než překonané, podřadné fáze; erotické, rytmické přecházení naopak zahrnuje neustálou propojenost mezi všemi rovinami bytí, z nichž žádná nás nikdy definitivně nezbavuje druhé.

Jedním možným popisem by pak mohl být ten, jenž propracoval Deleuze poukazujíce na to, že Sókratés (či Platón s jeho teorií idejî) láká krasavce a mladíky na to, co si „vymyslel“" $\mathrm{v}$ rámci svého erotického umění a toužení. ${ }^{\mathrm{ii}}$

\footnotetext{
${ }^{\text {i }}$ Srv. Halperin 1990. Opačně, tj. hierarchicky (a zde je dle nás podstata omylnosti celého výkladu) vykládá Sókratovu lásku ten, jemuž na moci nejvíc záleželo Alkibiadés: „Vězte, že mu nic nezáleží na tom, je-li někdo krásný, a naopak nad pomyšlení jím zhrdá...“ (Symp. 216d-e) Sókratovi nezáleží na pozemské kráse proto a jen do té míry, že je erotik, tj. je „mezi“, ale ne proto, že by byl někde na vrcholné scala amoris, že by „vlastnil“ vyšší postavení. Alkibiadés ř́iká pravdu, ale celý kontext jeho řeči je nepravdivý: je pravda, že Sókratés „zhrdá“ pozemskou krásou, ale není pravda, že se nad ni povyšuje.

${ }^{i i}$ Konstrukce či vymyšlenost světa idejí odpovídá běžnému popisu Platónova vymyšlení si samotné filosofie, v jejímž rámci se ideje či postava (,,pojmová osoba“) Sókrata-filosofa objevuje. K ,vymyšlení“ filosofie jako disciplíny se svými metodami a cíli, v protikladu k sofistice či jiným konceptům filosofie (Isokratés, Démokritos) viz např. Kraut 1992, s. 1-2, kde je řeč o ,invented
} 
Pravda sama je výmysl, erotická fantazie, kterou milující přitahuje pozornost dalších milujících, anterótů, rivalů. ${ }^{i}$ Sókratés musel vymyslet pojem „pravdy“, aby ho druzí vzali v potaz. Sókratés vymýšlí pravdu v zápase o druhé, o mladé krasavce. Milostný trojúhelník je zde sice zvláštní, nicméně popsatelný: Filosof se kolem krásných mladíků točí kvůli poznání, stejně tak ale předvádí poznání či moudrost, aby se kolem nich mohl točit. Kdo si dovolí říci, co je důležitější či konečnější? V erotickém kontextu se výše zmíněná triangulace, přechod $\mathrm{k}$ třetímu úhlu nejprve když budeme brát $\mathrm{v}$ úvahu žebřík lásky z Diotiminy řeči - otevírá v rovině pozemské, tělesné, kde se ukazuje, že milujícího touha po milovaném je inspirována či posilována dalšími erasty. Takto lze říci, že milující má či vymýšlí si svého milovaného proto, aby na něho „chytal“ jiné milující, s nimiž tímto soupeří, a tak zase posiluje svoji touhu. Když Diotima vytýká Sókratovi (a tak Sókratés Agathónovi, 204c), že Erós je milující a ne milovaný, pak to platí i v tomto řekněme hlubším smyslu: Sókratés je milující, který koneckonců miluje zase jen milující - soupeře a soupeření; jeho anterótem není milovaný, ale milující. ${ }^{\text {ii }}$

At' už je či není toto Sókratovo rozvinutí významu eróta v Platónových dialozích doložitelné i ve fragmentech, které nám dnes zůstávají po Sapfó, snad se nám předcházejícími úvahami podařilo naznačit, že Sapfó pracuje

philosophy“. Nightingale, 1995, s. 14: „The discipline of philosophy ... was not born, like a natural organism. Rather, it was an artificial construct that had to be invented..."

${ }^{i}$ Viz Deleuze, Guattari 2001. Od první kapitoly autoři systematicky rozvíjejí myšlenku, že filosofie není než práce s pojmy, které nejsou dané jako nebeská tělesa, nikde nečekají hotové, ale musí být neustále tvořeny daným myslitelem. Konkrétním př́kladem je jim Platón, který nazírá ideje, jejichž pojem ale nejprve musel vytvořit.

ii Tak viz např. dialog Faidros, který lze vyložit jako vzkaz Sókrata Lýsiovi či Platóna Isokratovi. Alkibiadovo přitahování Sókratem nicméně ukazuje, že erastés je krásný: nosí v sobě skryté „skvosty“, agalmata (216e6). Milující (Sókratés) je tak zároveň milovaný; to ovšem až druhotně - proto, že miluje krásné objekty, díky kterým je krásný, tvoří krásného člověka, moudrost atp. 
s erótem podobně jako Sókratés. Návaznost je zde přitom podle nás silnější než třeba mezi názory Sókrata a ostatními řečníky na téma erós $\mathrm{v}$ dialogu Symposion. Zde si přes všechno navazování Sókratés a jeho prrátelé stran povahy, činů či důležitosti eróta v lidském životě výslovně odporují. Fragmenty básníŕky ztělesňují - jakkoli nerozvinuté - popisy, které u Sókrata najdeme rovněž. ${ }^{i}$

Shrnutí: Konkrétně jsme popsali tři směry možného rozvinutí povrchní juxtapozice eróta sofistés a mythoplokos: práce $\mathrm{s}$ vždy podstatně ambivalentním erótem a jeho oslava; pletichaření s krasavci, které se děje výhradně skrze řeč a v řči (dialektické či básnické) krasavce vždy již opouští, a tak znemožňuje běžnou konzumaci lásky. Sapfó a Sókratés skrze eróty sofistés a mythoplokos přecházejí z roviny pozemského bytí na rovinu myšlení a krásy jako takových. Vymýšlení si v obou jejich př́padech není ovšem nutné chápat jako únik do světa věčné krásy, ale jako rytmické oscilování v meziprostoru těchto dvou světů.

${ }^{\mathrm{i}}$ Srv. např. Fortenbaugh 1966. 


\section{Literatura:}

Barabas, M., 2000, „Sókratova podivnost“, Reflexe 21, s. 85-106.

Cajthaml, M., 2007, „Ke vztahu pederastie a Platónovy filosofické teorie lásky“, in: Havlíček, A., Cajthaml, M. (ed.), Plato's Symposium, Praha, s. 108-124.

Carson, A., 1986, Eros The Bittersweet, Princeton University Press .

Deleuze, G., Guattari, F., 2001, Co je filosofie?, Praha.

Edmunds, L., 2006, „What was Socrates called?“, Classical Quarterly 56.2, s. 414-425.

Fortenbaugh, W., 1966, „Plato's Phaedrus 235c3“, Classical Philology, Vol. 61, No. 2, s. 108-109.

Furley, W. D., 2000, „Fearless, Bloodless ... like the Gods: Sappho 31 and the Rhetoric of Godlike“, Classical Quarterly 50.1, s. 7-15.

Halperin, M. D., 1990, „Why is Diotima a Woman?“, in: Halperin, M. D., Winkler J. J., Zeitlin, F. (ed.): Before Sexuality: The Construction of Erotic Experience in the Ancient Greek World, Cambridge University Press, s. 257-308.

Kraut, R., 1992, „Introduction to the study of Plato“, in: Kraut, R. (ed.), The Cambridge Companion to Plato, Cambridge, s. 1-50.

McCormick, P., 2007, „Eros and True Friendship in Plato's Symposium“, in: Havlíček, A., Cajthaml, M. (ed.), Plato's Symposium, Praha, s. 293-311. 
Nightingale, A. W., 1995, Genres in Dialogue: Plato and the Construct of Philosophy, Cambridge University Press.

Nussbaum, M. C., 2003, Křrehkost dobra, Praha.

Osborne, C., 1996, Eros Unveiled, Plato and The God of Love, Oxford University Press.

Parker, H. N., 1993, „Sappho Schoolmistress“, Transactions of the American Philological Association 123, s. 309-351.

Prior, W. J., 2006, „The Portrait of Socrates in Plato's Symposium“, Oxford Studies in Ancient Philosophy XXXI, s. 137-166.

Sheffield, F. C.C., 2006, Plato's Symposium, The Ethics of Desire, Oxford University Press.

Stern-Gillet, S., 2007, „Poets and Other Makers: Agathon's Speech in Context", in: Havlíček, A., Cajthaml, M. (ed.), Plato's Symposium, Praha, s. $86-107$.

Stigers, E S., 1979, „Romantic Sensuality, Poetic Sense: A Response to Hallett on Sappho“, Journal of Women in Culture and Society, vol. 4, no. 3, Chicago, s. 465-471.

Šedina, M., 1997, Sparagmos, Praha. 